\title{
PROBLEMY LITWY ŚRODKOWEJ 1920-1922 \\ MIĘDZYNARODOWA KONFERENCJA NAUKOWA, UNIWERSYTET WITOLDA WIELKIEGO W KOWNIE, 26-27 LUTEGO 2004 R.
}

W lutym 2004 r. w Kownie obradowała międzynarodowa konferencja naukowa poświęcona dziejom Litwy Środkowej. Konferencję zorganizowały wspólnie Katedra Historii Uniwersytetu Witolda Wielkiego w Kownie, Centrum Slawistyki UWW, Litewska Akademia Wojskowa, Związek Strzelców Litewskich oraz Instytut Polski w Wilnie.

Podczas dwóch dni spotkań roboczych uczestnicy i licznie zebrani goście wysłuchali referatów badaczy z Litwy, Polski, Łotwy i Białorusi. Po krótkiej części oficjalnej, jako pierwszy wystąpił Włodzimierz Suleja (Wrocław), który zaprezentował miejsce, jakie zajmowała Litwa w koncepcjach politycznych Józefa Piłsudskiego. Z kolei Witold Wojdyło (Toruń) w referacie zatytułowanym „Dokuczliwy karzet". Poglady narodowych demokratów na sprawy Wilna i Litwy Środkowej w latach 1918-1922 przedstawił zapatrywania największej siły politycznej w Polsce na sprawy litewskie w okresie eskalacji konfliktu polsko-litewskiego po pierwszej wojnie światowej. Krzysztof Buchowski (Białystok) ukazał proces powstawania Litwy Środkowej w 1920 r. jako element realizacji koncepcji federacyjnej, w którym niepoślednią rolę odgrywało środowisko wileńskich „krajowców”, natomiast Jacek Gzella (Toruń) swoje wystąpienie poświęcił stosunkowi wileńskiego publicysty i działacza politycznego, Władysława Studnickiego, wobec idei stworzenia Litwy Środkowej i jej porozumienia z Litwą. Pierwszą sesję zakończył Rimantas Miknys (Wilno) referatem Stanowisko litewskiej masonerii wobec Litwy Środkowej 1920-1922.

Po przerwie wysłuchano wypowiedzi Eriksa Jekabsonsa (Ryga) na temat meandrów łotewskiej polityki związanej z problemem funkcjonowania Litwy Środkowej. Waldemar Rezmer (Toruń) przedstawił potencjał militarny quasi-państwa kierowanego przez generała Lucjana Żeligowskiego, a Michał Klimecki (Toruń) omówił dzieje Dywizji Litewsko-Białoruskiej, w 1920 r. walczącej na polsko-litewskim froncie. Pierwszy dzień obrad zamknęły najpierw referat Wojciecha Śleszyń- 
skiego Strefa neutralna i pas graniczny między Polska a Litwa na terenie Litwy Środkowej 1920-1923, a następnie panelowa dyskusja moderowana przez Pranasa Janauskasa, szefa Katedry Historii UWW. Wszystkie referaty, a także przebieg rzeczywiście gorącej dyskusji z udziałem publiczności, symultanicznie tłumaczono na języki polski i litewski.

Drugiego dnia konferencji Andrzej Pukszto (Wilno) przedstawił referat zaty tułowany Inkorporacjoniści przeciwko federalistom: postawy polskich mieszkańców Wilna wobec Zarzqdu Cywilnego Ziem Wschodnich i polityki Józefa Pitsudskiego od kwietnia 1919 do lipca 1920 r. Następnie Dariusz Szpoper (Gdańsk) zaprezentował działalność Aleksandra Meysztowicza jako ostatniego przewodniczącego Tymczasowej Komisji Rządzącej Litwy Środkowej, a Zbigniew Karpus (Toruń) przeanalizował wystąpienia parlamentarzystów dotyczące Litwy Środkowej podczas obrad polskiego Sejmu Ustawodawczego. Kolejne wystąpienia badaczy litewskich poświęcono odzwierciedleniu stosunków litewsko-polskich w litewskiej opinii publicznej w latach 1920-1923 (Audrius Abromaitis - Wilno) oraz stanowisku litewskich władz wobec Litwy Środkowej (Česlovas Laurinavičius Wilno). Poprzerwie wysłuchano jeszcze referatów Esteli Gruzdiene (Kowno) o udziale litewskiego lotnictwa wojskowego w wojnie z Litwą Środkową w 1920 r. oraz Eduarda Mazko (Grodno) o roli Wilna w koncepcjach białoruskiego ruchu narodowego w pierwszych dziesięcioleciach XX w. Ostatnia wystąpiła Indrě Karčiauskaitě (Kowno) przedstawiając obraz Litwy ukazany w polskiej prasie wileńskiej w latach 1922-1923.Konferencję zakończył kolejny panel dyskusyjny. Materiaływ postaci tekstów referatów i zapisu dyskusji zostaną opublikowane w języku litewskim w kowieńskim kwartalniku „Darbai ir Dienos”. 